\title{
Morte em família: ritos funerários em tempo de pluralismo religioso ${ }^{1}$
}

\author{
Edlaine de Campos Gomes \\ Centro de Estudos da Metrópole/Cebrap
}

\begin{abstract}
RESUMO: A presente análise aborda aspectos significativos de uma pesquisa mais ampla que enfoca o complexo quadro de pluralismo religioso em uma rede familiar da camada popular e suas implicações no âmbito das transformações intrafamiliares e de vizinhança. Reflete também sobre como as novas escolhas por tal ou qual confissão religiosa, especialmente pentecostais, impõem ou não a adoção de novas atitudes diante do mundo. Os ritos funerários do casal que origina a rede familiar são tomados como situaçōes exemplares da tensão entre atribuição (herança) e aquisição (escolha), representada na aceitação ou recusa de participação ativa e conjunta das diferentes correntes religiosas na condução dos rituais familiares.
\end{abstract}

PALAVRAS-CHAVE: família, pluralismo religioso, exclusivismo, ritos familiares.

Nesse instante, a inversão dos papéis é extraordinária. É o homem vivo, o sacerdote, o médico, o parente sentado junto ao leito quem nada sabe e é o agonizante que tudo sabe.

(Ziegler, 1977, p. 271)

Em artigo recente (Gomes, 2007), observaram-se conflitos, acomodações, rupturas e continuidades provocados pela emergência do pluralismo religioso em uma rede familiar de camada popular, centralizada na 
Baixada Fluminense, região metropolitana do Rio de Janeiro. O catolicismo era a religiáo predominante. Este caracterizado no modelo pelo "sincretismo católico" brasileiro, entendido como hegemônico e englobante das práticas religiosas relacionadas às religiōes afro-brasileiras (Sanchis, 1994). O pano de fundo da análise é o panorama religioso brasileiro das últimas décadas, caracterizado por um pluralismo de tendência exclusivista, principalmente influenciado pela diversificação e pelo crescimento do campo evangélico pentecostal.

As narrativas dos entrevistados mostraram mudanças significativas nas relações familiares, tendo como um dos fatores mencionados as seguidas conversões de parte de seus membros às denominaçôes evangélicas. As escolhas conduzem à adoção de novas atitudes diante do mundo. A valorização da escolha individual em oposição à atribuição da religião familiar se apresenta como um dos valores estruturantes da cosmologia moderna. Nesse sentido, "a referência a um 'subjetivismo' busca enfatizar a preeminência da representação de uma escolha pessoal do sujeito, de uma presumida liberdade individual principial prevalecente no campo da experiência religiosa hoje" (Duarte et al., 2007, p. 4).

É importante ressaltar que foi em meados da década de 1980 que o pentecostalismo entrou de forma mais expressiva na rede familiar. Dado que acompanha o perfil do crescimento e da diversificação do campo pentecostal, como já foi apontado por diferentes autores (Freston, 1994; Fernandes, 1994, 1998; Mariz \& Machado, 1998; Contins, 1995). A proximidade da família pesquisada com o campo evangélico já vinha ocorrendo desde décadas anteriores. A Igreja Batista e a Assembléia de Deus eram as principais referências desse contato com o pluralismo religioso institucional, característica diretamente influenciada pelo grande crescimento e disseminação das igrejas evangélicas nos últimos quarenta anos. 
As relaçóes de sociabilidade e os novos modos de lidar com o corpo transformaram-se: a maneira de se vestir, cortar os cabelos, andar sempre com a Bíblia, imprimir nas conversas cotidianas temáticas religiosas, assumindo características de pregações e evangelização. Ter a "obrigação" de levar a "Palavra" para que todos tenham acesso à salvação faz que sejam necessários diálogos e mediaçôes nesse processo de comunicação, que envolve auto-identificação e reconhecimento mútuo entre as diferentes identidades religiosas. É reconhecida a influência de convertidos no processo de conversão de membros de familiares, amigos e vizinhos.

A observação etnográfica possibilitou a verificação da dinâmica do pluralismo religioso no âmbito da família e da vizinhança. Mais do que as novas configuraçôes das redes de pertencimento, diante das conversões às diferentes denominações evangélicas e das desfiliações das religiōes herdadas, observou-se a adoção de uma identidade religiosa exclusiva, mesmo entre católicos. Essa nova postura gerou transformações nas regras de sociabilidade, evidenciadas nas celebrações, festas e rituais. Os conflitos se tornam mais evidentes quando as identidades religiosas - marcadamente exclusivistas - buscam ocupar novos espaços e marcar presença em celebrações, rituais e festas. Encontros, festas e celebrações são eventos preciosos para a compreensão da dinâmica e das implicações das conversões religiosas. Há um rol de possibilidades de entrecruzamentos dignos de observação: dos núcleos familiares entre si, entre o convertido e seu núcleo, entre o convertido e a rede mais ampla, entre o convertido e a vizinhança, entre outras. 


\section{A casa compartilhada: característica da família extensa}

"Vou passar no Gato Preto" e “o aniversário vai ser no Gato Preto” são apenas duas das frases utilizadas pelos membros da rede familiar que demonstram a conexão entre a casa dos pais e o bairro no qual construíram sua história. Gato Preto é uma pequena localidade dentro do Bairro Éden. Originalmente, não havia tal demarcação, somente com o crescimento populacional é que as localidades foram ganhando novos nomes. Essa família "passar no Gato Preto" significa ir até a casa do casal Geraldo e Maria, caracterizada como o centro de referência de todos os seus membros, pelo menos até a morte do patriarca. A concepção de casa, como é ampliada, é extraterritorial, abarcando até mesmo as moradias daqueles que não convivem diariamente no mesmo espaço.

Marcelin (1999, p. 12) aponta a equivalência entre os termos família e casa em seu material de pesquisa com integrantes de famílias negras do Recôncavo Baiano. Este autor observa que a casa é o "lugar no qual e pelo qual" os integrantes da rede familiar se definem e sustentam sua existência social como pessoa. $\mathrm{O}$ material da família pesquisada na Baixada Fluminense também apresenta a equivalência entre casa e família. No entanto, os termos aparecem integrados na combinação tripartite "bairro-casa-família", na qual os integrantes da rede se referenciam. Sugiro que podemos utilizar esse modelo quando tratamos particularmente da relação casa-pais-filhos. É importante destacar que a referência vai sendo modificada de acordo com a geração e com o tipo de relação que se tem com "a casa" - morador fixo, transitório ou não morador.

O modelo de análise apresentado por Marcelin aponta dois níveis indissociáveis para a compreensão das relações entre os integrantes das famílias tradicionais: (1) casa e (2) configuração de casas. Esta última é entendida como um "conjunto de casas vinculadas por uma ideologia 
da família e do parentesco - que conformam um sistema de sentidos, mediante o qual a casa e a configuração se constroem" (id., 33).

A análise das transformaçôes ocorridas na rede familiar da Baixada Fluminense e de suas implicações geracionais aponta para mudanças de referência, que envolve a noção de "configuração de casas". A adoção de novas casas-referência é perceptível na terceira geração. Em suas pesquisas, Simoni Guedes aponta a importância dos "quintais" para a organização familiar e as relações de parentesco entre as classes trabalhadoras, no sentido da formação de novos núcleos dentro da rede familiar. Define a categoria "quintal" como:

[...] os conjuntos de casas que foram construídas ao longo do tempo num mesmo lote ou terreno, a partir de uma casa inicial, em que o proprietário realiza, ele mesmo, ou permite a realização de novas construções. Podem apresentar-se em densidade variável: há quintais com três, quatro ou cinco casas e muito espaço disponível, há outros em que mais de dez casas encontram-se lado a lado, outros ainda que cresceram verticalmente em direções dificilmente imagináveis, compondo uma arquitetura surpreendente. (Guedes, 1998, p. 9)

No caso específico da rede familiar analisada, os primeiros cômodos - seis - foram construídos pelo próprio pai com o objetivo de servirem de renda. Esses eram alugados para solteiros ou casais conhecidos ou indicados por parentes e vizinhos. São chamados de "cabeça de porco", por sua metragem não ser maior que 3 metros quadrados e não ter banheiro. Era apenas um único banheiro para todos os inquilinos. Na época, o terreno não possuía esgoto - fato que perdurou até recentemente. O esgoto corria pela pequena área que mediava o terreno.

Aos poucos, com o início da vida conjugal dos filhos, o casal que originou a rede passou a acolhê-los como inquilinos, sem receber 
nenhum benefício econômico. $\mathrm{O}$ intuito era ajudar na estruturação das novas famílias, já que não havia possibilidade de se manterem em outro local. Os casais passaram a ocupar os pequenos cômodos integrados, que foram sendo transformados em casas individualizadas.

A casa principal, mais ampla, também serviu de lugar de passagem, principalmente em relação às filhas mulheres. Em momentos diferentes, ela foi reestruturada para receber as duas filhas mais novas, que se casaram e moraram junto com os pais por algum tempo. A casa foi adaptada, na medida do possível, para que os cônjuges tivessem uma certa privacidade. Um dos cômodos foi ampliado, sendo utilizado como quarto e cozinha. Cada casal não permaneceu mais que dois anos nessa convivência. Logo, buscaram novas alternativas de moradia. Uma das filhas mudou-se para a casa dos pais do marido. A outra irmã, antes de construir com o marido a própria casa, passou a morar em uma quitenete no terreno da casa de uma das irmãs mais velhas, que vivia em outra região do mesmo bairro. Os dois casos demonstram como os "quintais" representam um modelo representativo de organização e reprodução das relações familiares presente nas camadas populares.

O sistema de residência segue a lógica da patrilocalidade de maneira geral: as esposas seguem seus maridos após o casamento, enquanto os filhos homens agregam as esposas e os filhos à família de seus pais. Essa dinâmica tem lugar de destaque na configuração do "quintal". Foram os filhos com suas respectivas famílias que se fixaram nesse espaço familiar. Dos seis filhos, apenas dois construíram suas vidas em outros locais. Um deles se casou com uma mulher de família circense e o outro se converteu à Igreja Batista e se casou com uma integrante da mesma congregação religiosa. Nenhuma das filhas pode ser caracterizada como moradora permanente do quintal. A irmã mais velha jamais morou nesse lugar após o casamento. A segunda filha mais velha se casou com 14 anos e foi morar com seu marido em outro local do bairro, vindo a ocu- 
par esporadicamente um dos cômodos do quintal somente após o falecimento do marido no início da década de 1990. As outras duas passaram pela casa dos pais durante os primeiros anos de casamento, não permanecendo aí por muito tempo.

Outra característica importante nesse tipo de configuração familiar é a forma como as crianças são criadas - no caso específico, os netos. A circulação das crianças é a forma como a rede familiar organiza a criação das crianças. Fonseca (1995) observa que essa é uma dinâmica que orienta a organização familiar, constituindo-se como um sistema de valores particular aos grupos populares urbanos. Nesse sentido, a circulação de crianças é

[...] um dos processos rotineiros de socialização, as crianças transitam entre as casas de diversas "mães": madrinha, vó, vizinha e genitora. Calcada na análise de sociedades complexas que admite a possibilidade de lógicas múltiplas, é uma noção construída para ir de encontro aos estereótipos habituais que vêem, entre "pobres", nada além de patologia e desorganização. (id., p. 188)

Existem pelo menos três níveis de circulação de crianças dentro da rede familiar aqui analisada. (1) No primeiro e mais corriqueiro, as crianças passam pelas diferentes casas por pequenos períodos: pode ser para usufruir das refeições ou para que as mães possam realizar alguma atividade fora de casa. É mais comum que esse tipo de circulação seja mais intenso e diversificado: um dia a criança almoça na casa dos avós e janta na casa da tia, e assim sucessivamente. (2) No segundo tipo, as crianças ficam por períodos mais longos sem a presença efetiva dos pais. Nesse caso, o principal exemplo é quando ambos os pais trabalham fora. (3) O terceiro tipo é mais radical: a criança permanece efetivamente sob a responsabilidade de um parente ou integrante da rede por um período 
mais longo ou até que se torne "independente". Nenhum desses casos é percebido como adoção, em seu sentido legal, quando todas as responsabilidades e conseqüências jurídicas passam a ser de quem detém a tutela da criança. Os verbos utilizados são cuidar e ficar.

Dado importante a ser mencionado é que a circulação não é vista como abandono, as crianças não estão sendo dadas a outros, mas estão sendo cuidadas por pessoas afins, que comungam de uma mesma lógica familiar (Sarti, 1996). Nesse ponto, não há diferença entre a circulação entre parentes que vivem no mesmo quintal e aquela entre os que moram fora deste. Como foi mencionada, a noção de casa é ampliada e inclui os parentes externos ao quintal.

\section{Ritos familiares e pluralismo religioso: celebração da morte e legitimidade da conversão}

As festas e celebrações - incluindo funerais - são eventos preciosos para a compreensão de conflitos e possibilidades de acomodação que cercam as relações de sociabilidade em contextos de pluralismo religioso. Um evento marcante para a discussão sobre conflitos e acomodações no contexto de pluralismo religioso intrafamiliar nas classes populares ocorreu em torno da doença e morte do patriarca da família em 1988. Mais do que falta de acesso à rede hospitalar e carência de recursos financeiros, a espera da morte e a realização do velório em casa representavam um traço tradicional na família. Seria uma "maneira solidária e gregária de lidar com a morte", como nos diz Reis (1996, p. 102). Uma "morte tradicional" (Ariès, 1981), inscrita no contexto da casa e da família.

Homem alto, muito magro, mulato, marceneiro, sem o dedo indicador direito - perdido em um acidente de trabalho -, nunca coube em sua cama. Suas pernas, da canela até os pés - descreveu sua filha -, fica- 
vam apoiadas em uma banqueta depois de seu adoecimento. Ele não se movia sozinho devido às dores que sentia durante aqueles meses. A filha mais velha relata os últimos dias de seu pai:

"Esperou a morte chegar. Pediu que eu esticasse suas pernas, uma delas estava dobrada, e colocasse suas mãos unidas sobre seu peito. Foi nesta posição que ele morreu".

Tempos antes de falecer em seu próprio quarto, durante o período de um intenso sofrimento provocado por câncer no pulmão, seu Geraldo recebeu a visita de uma de suas noras, esposa de seu terceiro filho ambos recém-convertidos ao pentecostalismo -, que foi até ele para "levar a Palavra”. Anteriormente, ela era conhecida por manifestar uma entidade chamada "Vovó Catarina", e, por ser rezadeira, era procurada pela vizinhança para rezar "espinhela caída", "mau-olhado", entre outros. No momento dessa visita, encontrava-se lá a filha mais velha de seu Geraldo, também fazendo uma visita.

O cenário era este: o patriarca doente em seu leito de morte, a filha mais velha e a nora evangélica. Nesse contexto de aflição, foi permitido que se fizesse uma oração nos moldes pentecostais, ainda que a antipatia com essas práticas pairasse no ar. Realizar visitas e orar pela cura dos doentes é uma prática pentecostal. "Aceitar Jesus" é um imperativo para a salvação proposta por esse campo. Não foi de modo diferente que ocorreu a oração feita para seu Geraldo. Sua nora tentava mostrar em suas palavras o quanto seria importante que ele "aceitasse Jesus". Sua salvação dependia dessa resposta. Em determinado instante, o doente ergueu um de seus braços.

Com esse gesto iniciou-se uma grande controvérsia, que não teve desfecho quase duas décadas depois. A "conversão do patriarca" se tornou um mito familiar crítico, cercado por uma aura de sentimentos 
conflitantes, que devem ser interpretados segundo a perspectiva de cada grupo religioso em questão - no caso, o grupo católico e o grupo evangélico pentecostal. As interpretações desses grupos sobre os acontecimentos foram orientadas por duas questôes: (1) resistência e ênfase da hegemonia católica e (2) legitimação da posição evangélica na família.

A mão erguida foi interpretada de maneira totalmente diversa pelos presentes. A filha católica sustenta que o pai levantou o braço em uma manifestação de seu desagrado com as orações da nora, mandando-a ir embora. Ele estaria expressando uma recusa e não uma aceitação. A interpretação da outra personagem foi oposta. $\mathrm{O}$ mesmo ato seria a confirmação, uma resposta positiva para a questão "você aceita Jesus?".

"Ela disse que ele se converteu, virou crente, que aceitou Jesus. Eu disse que papai já tinha aceitado Jesus há muito tempo. Papai era católico desde quando ele nasceu, ele já era de Jesus. Foi aquela confusão. Chama um, chama outro [...]. Foi aquela confusão. Mentira! O papai estava lá sofrendo pra caramba, num sufoco, naquela hora da agonia. Ele fez assim com a mão, e ela disse que ele aceitou Jesus. Ele aceitou há muito tempo.”

A controvérsia sobre a conversão ou não do patriarca continuou no ritual funerário. Todos os familiares estavam presentes. Havia representantes das duas correntes religiosas em conflito. A condução dos rituais seria a prevista pela tradição religiosa familiar. Um padre católico faria a "encomenda" do corpo. No entanto, o tema da conversão do defunto veio à tona. Os familiares evangélicos reivindicaram seu lugar nos ritos funerários, legitimado pela tese da conversão de seu Geraldo.

Católica praticante e autoridade moral da família, a irmã mais velha não permitiu manifestaçóes evangélicas no velório e no enterro, impedindo as oraçôes. 
Revista de Antropologia, São Paulo, USP, 2006, v. 49 No 2.

“Eles queriam levar pastores. Não! Papai já tinha aceitado Jesus. Não precisava de oração. Eu falei mesmo: o papai já aceitou há muitos anos, não precisa de mais oração não!"

Foi com o ritual católico que seu Geraldo foi enterrado, aos 72 anos, junto com a própria interpretação sobre os eventos ocorridos acerca de sua conversão.

Novos detalhes sobre esse evento foram dados pelo neto mais velho de seu Geraldo - também católico e primeiro dos cinco filhos da filha mais velha de seu Geraldo. Segundo ele, seu avô pediu que ele chamasse um padre para ministrar a extrema-unção. Um padre amigo da família foi chamado e realizou o ritual no próprio quarto do enfermo. Esse informante contou tal fato para confirmar a identidade católica de seu avô, principalmente porque não tinha conhecimento dessa controvérsia, mostrando-se sensivelmente afetado e contrariado. Tratou do assunto como uma "acusação" capaz de manchar a memória de seu avô.

É importante ressaltar que houve uma mudança no processo de aceitação das conversões religiosas e da participação efetiva dos evangélicos nas comemorações familiares durante as décadas posteriores - em 1990 e 2000 -, principalmente com relação à terceira geração, representada pelos netos. Ao mesmo tempo, os grandes encontros da família - todos os dez filhos vivos de seu Geraldo e de dona Maria, seus respectivos cônjuges, netos e agregados - tornaram-se escassos.

Desde a morte de seu Geraldo, dona Maria passou a morar com a filha mais velha. Nunca retornou para viver em sua casa após o velório. "Muito católica", carregava um terço dentro de suas roupas, junto ao peito. Todas as noites rezava antes de dormir e não era incomum vê-la durante o dia rezando com seu rosário. Costumava andar com medalhinhas de Nossa Senhora do Carmo, presas com alfinetes em sua roupa. 
Várias vezes ouvi o mesmo relato sobre o poder religioso que dona Maria, embora muito católica, tinha sobre representantes das religióes afro-brasileiras. A história que segue ressalta o tipo de sincretismo religioso existente entre as classes populares e o pluralismo tradicional ${ }^{2}$ do campo religioso brasileiro (Sanchis, 1994; Mariz \& Machado, 1998).

A filha mais velha de dona Maria conta que o reconhecimento de seu "poder" vinha dos próprios integrantes da umbanda e do candomblé. Eles diziam que sua mãe era "filha de Nanã" e "protegida de Oxalá”. Quando passava na rua e algum filho-de-santo percebia sua presença, logo fazia reverências: abaixava a cabeça e pedia sua bênção. Conta que sua mãe jamais tinha participado de "rituais de santo", não era "feita" nem gostava disso, mas uma vez foi convidada para uma festa em um terreiro. Ao chegar lá, ficou assustada quando começaram a lhe fazer reverências, até mesmo "ajoelhavam a seus pés".

Essa passagem da vida de dona Maria é contada com grande ênfase e, em nenhum momento, a ligação com as religiōes afro-brasileiras, mesmo que distante, aparece como uma relação negativa. Os episódios de contato com as "pessoas-de-santo" não afetavam a identidade católica de dona Maria. Não havia uma disputa institucional em jogo entre católicos e afro-brasileiros. $\mathrm{O}$ mesmo não ocorre no contato com evangélicos.

As mudanças tornaram-se evidentes no funeral de dona Maria em 2003. Ao contrário de seu marido, que morreu e foi velado em casa, dona Maria faleceu, aos 87 anos, no hospital e foi velada no cemitério. A morte não era mais um momento a ser partilhado com a família dentro do espaço da casa. Deveria ser intermediada pela instituição hospitalar - "morte moderna” (Ariès, 1981), "medicalizada" (Foucault, 1999) e afastada da vida cotidiana dos parentes e vizinhos (Elias, 2001). Nenhum familiar quis "vestir a falecida” para prepará-la para o funeral. 
As roupas foram enviadas para o hospital pela filha mais velha. Lá, uma enfermeira foi solicitada para realizar o procedimento. $\mathrm{O}$ contato com o corpo sem vida do ente querido estava em processo de transformação.

No funeral - realizado em um espaço dentro do próprio cemitério filhos, noras, genros, netos, bisnetos, vizinhos e amigos antigos estavam presentes. Figura muito querida de todos, no alto de seu 1,40 metro, era quase uma "lenda viva", disse um de seus netos. Seus filhos e netos costumavam carregá-la nos braços de um lado a outro. Raramente falava alguma coisa, somente ria das situaçôes e das conversas. Mas era muito vaidosa, pintava os cabelos de preto, fazia sobrancelha, pintava as unhas e adorava vestidos novos. "Não contrariava ninguém."

Todos achavam que dona Maria "não morreria mais". Por diversas vezes esteve internada no CTI (Centro de Terapia Intensiva). Os médicos a desenganaram uma dúzia de vezes. Um de seus netos conta que:

"Ela tinha o 'coração grande' e por isso não teria muito tempo de vida. Brincávamos com essa história. Tão pequena, com um coração tão grande. Nas últimas internações, os parentes pararam de se preocupar, pois ela voltaria mesmo. Na última vez, quando ela morreu, nós nem cancelamos o almoço da primeira comunhão de meu sobrinho. Ligaram para a gente dizendo que ela estava nas últimas. Não nos demos conta de que poderia ser verdade. Lá pelas três da tarde nos ligaram dizendo que ela tinha falecido. Seria verdade mesmo? Tínhamos que comprovar. Ligamos várias vezes para o hospital para saber se era verdade".

Momentos antes do enterro propriamente dito, os netos convertidos ao pentecostalismo tomaram a palavra e fizeram orações em voz alta. A baixa escolaridade e a espontaneidade das falas eram evidentes. Não faltaram "aleluias!" e "Senhor Jesus". Não foram impedidos de manifes- 
tarem sua presença, sua fé e suas homenagens. Embora olhares de censura e crítica continuassem a existir, o lugar do pluralismo religioso intrafamiliar estava sendo efetivamente reconhecido.

O cortejo fúnebre se encaminhou até o local onde o corpo seria enterrado. Chegando lá, novas orações foram realizadas. Um padre católico não estava presente naquele dia, não havia nenhum disponível. São poucos os padres para atender todas as paróquias e comunidades católicas da região. Grande parte dos rituais e celebraçóes é coordenada por leigos, os chamados "ministros da Palavra". Isso ocorre também nos funerais. A oração do "Pai Nosso" congregou todas as facções. No entanto, o ritual católico ainda prevaleceu com as orações finais e a "encomenda" do corpo.

A percepção quase mítica que baseia as interpretações sobre a forte presença de dona Maria no imaginário de seus parentes pode ser um dos motivos para a recusa em tocar seu corpo. No entanto, essa recusa também vem em compasso com a medicalização e a higiene, principalmente identificada com determinados núcleos familiares da rede que privilegiaram a escolarização de seus integrantes. A participação das crianças nos funerais é um dos exemplos da presença de combinações e atravessamentos de aspectos modernos nas camadas populares.

A presença ou ausência de crianças nesse cenário colabora para a análise das possíveis combinações e transformações que ocorrem na família. Nos dois funerais mencionados, havia a presença de crianças - netos e bisnetos -, que corriam e brincavam no mesmo espaço onde os corpos estavam sendo velados. Algumas delas se aproximavam do caixão e miravam o rosto do morto com olhar de curiosidade e destemor. Embora tristes pela morte dos avós, não estavam afastadas desse momento crítico.

As crianças estão integradas ao evento em si. O afastamento da morte se realiza no ritual pós-funeral orientado pela purificação; esta tem um peso significativo no caso das crianças. Ao retornar do enterro, o 
afastamento do morto e do cemitério, principalmente do contato com a "terra contaminada", dava-se com a realização de alguns procedimentos: não entrar em casa com os sapatos utilizados no funeral; tomar banho completo, incluindo lavar os cabelos; lavar todas as roupas e os calçados que tiveram algum contato com a "morte". Os objetos e o próprio corpo de quem participou dos rituais são considerados impuros e, por isso, perigosos para o processo de reordenação da vida cotidiana pósmorte de um ente querido. Segundo um informante, estes poderiam "contaminar o lar com impurezas e com a morte". Nesse sentido, a purificação é necessária para retornarem ao estado anterior, desvinculado da morte. É possível perceber que, para além de servir de proteção contra possíveis doenças, a purificação tem um sentido de novamente colocar em oposição a morte e a vida (Douglas, 1976).

Uma postura diferente aparece identificada com a premissa "morte não é assunto de criança”, especialmente no que tange a sua presença no cemitério. Criança e morte são dois elementos antagônicos nesse tipo de percepção. As crianças não participam de nenhuma etapa dos ritos funerários, são apartadas do morto e de tudo que o cerca.

Ao partir da idéia de que há nítidas distinções entre o que seria uma atitude tradicional e uma atitude moderna diante da morte e dos eventos, tento perceber as diferentes orientaçóes que interagem na família analisada. Ressalto que a atitude moderna está diretamente relacionada aos núcleos com maior investimento na escolarização de seus membros - principalmente em relação à terceira geração da família, que conta com advogado, médico, professores, entre outras profissões liberais.

Destaco uma resposta à pergunta que fiz sobre o que as pessoas pensavam sobre levar os filhos aos velórios e enterros.

"Eu só não levei minha filha ao enterro da avó porque o pai não deixou. Tinha várias crianças lá. Não vejo problema nisso. Mas acho que a criança 
só pode participar de enterro quando ela já pode entender o que é a morte. Uma criança de 3 ou 4 anos não tem essa capacidade. Elas têm que saber: a gente nasce, cresce, reproduz e morre. Com 9 anos, já entende isso. Mas é claro que não a deixaria tocar nas coisas nem ficar correndo." (Esposa de um dos netos)

Esse trecho é um outro formato possível para a combinação ou não dos temas morte e criança. A entrevistada, que possui o terceiro grau completo, apontou em sua resposta três informações importantes que caracterizam uma atitude moderna diante dos temas morte e criança: (1) a especificidade da criança enquanto uma etapa do desenvolvimento humano; (2) os graus de maturidade, conectando faixa etária e reflexividade; (3) o controle e autocontrole da criança no ambiente da morte - o cemitério. Nesse sentido, a criança pode ter contato com a morte, mas precisa seguir determinadas restriçōes. Ao mesmo tempo, esse contato atua quase que pedagogicamente para o aprendizado do processo biológico da vida e da morte.

\section{Considerações finais}

Nas narrativas das entrevistadas católicas, as conversões às novas confissões religiosas, especialmente às igrejas evangélicas, são consideradas como fatores significativos para a dificuldade de organizar os rituais familiares. Seria mesmo o fator de desarticulação da família extensa. A idéia central é que os laços consangüíneos são desvalorizados quando há conversão. “Os irmãos agora são eles!”, disse a liderança católica da família. É com certa mágoa e acusação que ela expressa o novo sentido de família que os convertidos adquirem. Em um desabafo, continua dizendo que: 
Revista de Antropologia, São Paulo, USP, 2006, v. 49 no 2.

"Ficou muito difícil. [Reflete alguns segundos.] Se tiver uma coisa de família, mas se eles tiverem que ir para a igreja, não deixam de ir para a igreja para estar com a família. É aquele negócio, a família deles é mais lá. Eles consideram mais lá. Eu acho assim, que eles consideram mais irmão os de lá que os irmãos mesmo. Só esse negócio de aniversário, fazer bolo, levar para partir na igreja e deixar os outros olhando... Mora lá nos fundos, passa com bolo cheiroso e pudim e leva para a igreja. Os irmãos estão ali, no mesmo quintal e não ganham nenhum pedaço. Não pode! Há uma separação. Eles separam, sim. Eles separam. Se convertem e ficam se sentindo o máximo. Aí, os sobrinhos pequenos vão porque vai cortar o bolo lá [na igreja]. Quer dizer, é um chamariz. Igual na macumba, quando tem bolo e guaraná, o pessoal vai. Igual Cosme e Damião. Aí enche a igreja."

A comparação entre evangélicos e "macumba" em relação às estratégias proselitistas é evidente nessa fala. Além de serem vistos como um chamariz, as celebraçôes e os rituais passam a ser encarados como espaços de competição e legitimação. A parte católica expressa ressentimento e receio de que a família extensa seja desintegrada pelas conversóes. Por outro lado, os membros que se convertem às confissóes evangélicas buscam legitimar o lugar dentro da família organizando festas e celebraçôes. Quando perguntada sobre a participação dos "crentes" nas cerimônias e festas e nos demais encontros familiares, a irmã mais velha e elemento central na rede, entre risos, disse:

"Agora a gente deixa eles orar o quanto quiserem... Mas uma vez recebi a visita de uma cunhada, que toda vez que vinha aqui ficava falando da igreja. Eles acham que só eles estão certos. Dizem "tá amarrado". Pode desamarrar que não tem nada amarrado aqui em casa. Eu disse: olha, aqui na minha casa eu rezo, você ora, e orar e rezar é a mesma coisa. Eu tinha che- 
gado da missa, com o livreto de Domingo. Eu comecei a ler. Li do início até o final. Ela teve que ficar ouvindo. Nunca mais ela me encheu o saco.”

Percebe-se uma certa aceitação ao pluralismo emergindo na rede familiar. No movimento de aceitação do "outro" - no caso, aceitação entre evangélicos pentecostais e católicos - ocorre, concomitantemente, a afirmação da identidade católica exclusiva. Vê-se o movimento de exclusivismo religioso não somente no caso evangélico. Os remanescentes do catolicismo se posicionam diante do pluralismo religioso assumindo uma postura contrastiva. As tensões permanecem mesmo após a conquista de espaço das novas correntes religiosas dentro da família. Podemos observar isso na oposição entre "família de fé" e "família de sangue”, e "irmãos de sangue” e “irmãos de fé” (cf. Novaes, 1985).

Ao mesmo tempo em que ocorre um afastamento da família extensa, acontece um englobamento pela "família de fé" adquirida. Tal movimento não se dá sem tensões e ajustes. Esse processo de individualização se torna incompatível com a centralidade da família extensa. É nesse sentido que os convertidos são acusados de "se sentirem o máximo". A conversão é lida como traição na medida em que vai contra a família. De alguma forma, aparece como transgressão à ordem familiar preestabelecida. Em um lócus pautado na noção de "pessoas relacionais destinadas a integrar outras e idênticas unidades familiares [...], é antes essa família ou 'grupo doméstico' do que o sujeito social isolado que valorizamos sob a categoria Indivíduo" (Duarte, 1995). A autoridade tradicional - relacional - é abalada pela autoridade individual, sobretudo quando há aquisição de um novo status do converso dentro da dinâmica familiar.

A disputa por espaço assume outra dimensão quando se considera o lugar de gênero nos arranjos familiares. A recorrência de adesão às práticas religiosas da mãe do marido tem sido verificada na terceira geração 
da família. A sogra assume um papel crucial na adoção de um novo ethos religioso pela nora, mesmo que o cônjuge não freqüente a denominação de sua mãe. Esse processo deve ser analisado em conjunto com a noção de patrilocalidade (regra de residência), uma vez que são as mulheres da rede familiar estudada que se mudam para os "quintais" das famílias de seus maridos. O quintal aqui é entendido de uma maneira mais ampla, considerando os domínios morais da respectiva família de adoção. A adesão à nova família não ocorre sem tensão, principalmente quando também inclui a adoção da confissão religiosa da família do marido, tornada evidente na realização do casamento religioso (Gomes, 2006).

Nas conversōes ao campo evangélico, as relações de aliança assumem uma dimensão que extrapola aquelas da família de "sangue". A família extensa é substituída pela "família de fé", que promove a construção de núcleos familiares de preferência intraconfessional. Nesse sentido, não se trata de um mero abandono da idéia de família, mas de um outro formato e constituição da família. Além de privilegiar os "irmãos de fé", o convertido adota comportamentos distintos dos de antes da conversão. Essas mudanças podem ser encaradas pelos membros da rede familiar como positivas ou negativas. No primeiro caso, a conversão é positiva quando promove mudanças individuais de comportamento que levam ao abandono de práticas vistas como desordens ético-morais, relacionadas a alcoolismo, drogas, sexualidade, entre outras. Por outro lado, a perspectiva católica percebe as conversóes de forma negativa quando as novas práticas adotadas pelo convertido substituem a relação com os familiares consangüíneos.

A rede familiar analisada passou por significativas mudanças com a iminência do pluralismo religioso com teor exclusivista, incrementado pelas conversões de parte de seus membros às denominaçôes pentecostais. A participação dos evangélicos nas celebrações e nos rituais familiares é percebida pelos católicos como uma cortesia, por respeito ao bem 
maior - à família. Por outro lado, os evangélicos conquistam e afirmam seu espaço por meio da "ação no mundo" (Weber, 1982), característica essencial dos renascidos. Em grande parte, seguindo o caráter proselitista, englobando a vida familiar pela religião. Hoje, são eles os que mais realizam festas e celebraçôes que objetivam agregar toda a rede familiar. A relação é ambígua. Por um lado, a mudança de religião pode ser reconhecida como uma ação séria, caso ocorra uma adesão comprometida identificada pela fidelidade religiosa. Em outro sentido, o argumento católico, ainda após décadas, pode insistir em justificar e até em duvidar das conversões, desqualificando-as.

Retomando a epígrafe que iniciou o artigo, somente seu Geraldo saberia dizer algo sobre sua suposta conversão. É o único que "sabe tudo" sobre o evento. No entanto, nunca pôde expor sua própria versão devido à morte iminente. As vertentes católica e pentecostal permanecem com suas interpretações sobre a conversão do patriarca. Ambas compõem o imaginário da família e perpetuam a associação, a disputa por legitimidade. As tensões movidas pela incorporação efetiva do pluralismo religioso nas relações permanecem centrais na ordenação da dinâmica familiar. Religião e família, em suas distintas conformaçōes, estão em constante interação. Talvez seja interessante pensar, nesse sentido, não em uma oposição entre "família de fé" e "família de sangue", mas refletir sobre as possíveis configurações de uma família de sangue com diferentes tipos de fé. 


\section{Notas}

1 Este artigo apresenta resultados da pesquisa "Os irmãos agora são eles: família e trajetórias em contexto religioso plural”, que visava compreender conflitos, acomodações, rupturas e continuidades provocados pela emergência do pluralismo religioso em uma família da camada popular. A pesquisa foi desenvolvida no período de março de 2005 a fevereiro de 2006 como atividade pós-doutoral no Programa de Pós-Graduação em Antropologia Social do Museu Nacional/UFRJ. Pesquisa desenvolvida no âmbito do Projeto de Pesquisa "Família, Reprodução e Ethos Religioso", financiado pela Fundação Ford/FINEP/CNPq, coordenado pelo professor Luiz Fernando Dias Duarte, do Museu Nacional/UFRJ.

2 Apenas um episódio da vida religiosa de seu Geraldo aparece associado a esse tipo de religiosidade sincrética. Quando um de seus filhos ficou muito doente, seu Geraldo o levou a um pai-de-santo. Certa vez em que estava indo de trem levar o filho quase desfalecido ao médico, foi interpelado por uma mulher, que disse que o problema deste não seria resolvido pela medicina e, em seguida, deu-lhe o endereço do terreiro do pai-de-santo. Mudando seu caminho, foi até lá para uma "consulta". Segundo consta, seu filho realmente teve uma melhora.

\section{Bibliografia}

ARIÈS, P.

1981 O homem diante da morte, Rio de Janeiro, Francisco Alves.

CONTINS, M.

Tornando-se pentecostal: um estudo comparativo sobre pentecostais negros nos EUA e no Brasil, Rio de Janeiro, pp. 249, tese, ECO/UFRJ.

DAMATTA, R.

A casa e a rua: espaço, cidadania, mulher e morte no Brasil, Rio de Janeiro, Rocco.

DOUGLAS, M.

1976

Pureza e perigo, São Paulo, Perspectiva. 
DUARTE, L. F. D.

1995

"Horizontes do indivíduo e da ética no crepúsculo da família", in Famílias em processos contemporâneos: inovaçôes culturais na sociedade brasileira, São Paulo, Loyola.

1999 "O império dos sentidos: sensibilidade, sensualidade e sexualidade na cultura ocidental moderna", in HEILBORN, M. L. (org.), Sexualidade. O olhar das ciências sociais, Rio de Janeiro, Jorge Zahar, pp. 21-30.

DUARTE, L. F. D; GOMES, E. C.; JABOR, J.; LUNA, N.

2007 "Família, reprodução e ethos religioso - subjetivismo e naturalismo como valores estruturantes", in Família e religião, Rio de Janeiro, Contra Capa.

ELIAS, $\mathrm{N}$.

$2001 \quad$ A solidão dos moribundos, Rio de Janeiro, Jorge Zahar.

FERNANDES, R. C.

1994 "Governo das almas: as denominações evangélicas no Grande Rio", in Nem anjos nem demônios: interpretaçôes sociológicas do pentecostalismo, Petrópolis, Vozes.

1998 Novo nascimento: os evangélicos em casa, na Igreja e na política, Rio de Janeiro, Mauad.

FONSECA, Cláudia

1995 "A noética do vídeo etnográfico", Horizontes Antropológicos, Porto Alegre, ano 1, n. 2: 187-206.

FOUCAULT, Michel

1999 Microfisica do poder, Rio de Janeiro, Graal.

FRESTON, Paul

1994 "Breve história do pentecostalismo brasileiro", in FERNANDES, R. C. Nem anjos nem demônios: interpretaçôes sociológicas do pentecostalismo, Petrópolis, Vozes.

GIUMBELLI, Emerson

2002 O fim da religião: dilemas da liberdade religiosa no Brasil e na França, São Paulo, Attar. 
GOMES, E. C.

"Os irmãos agora são eles: conseqüências do pluralismo religioso numa rede família”, Primer Congreso Latinoamericano de Antropología, Rosário. (Cd-rom)

2006 "Parente não é família: conjugalidade e tensões entre 'irmãos de sangue' e 'irmãos de fé"”, 30 Encontro Anual da ANPOCS, Caxambu. (Cd-rom)

2007 "Família e trajetórias individuais em um contexto religioso plural", in DUARTE et al. (orgs.), Familia e religião, Rio de Janeiro, Contra Capa.

GUEDES, S. L.

1998

"Redes de parentesco entre trabalhadores urbanos: tecendo relações a partir de quintais", Cadernos CRH, n. 29: 189-208.

HERVIEU-LÉGER, D.

1999 Le pelèrin et le converti, Paris, Flamarion.

JACOB, C. R. et al.

2003

Atlas da filiação religiosa e indicadores sociais no Brasil, Rio de Janeiro, PUC-RJ/ Loyola.

MARCELIN, Louis Herns

1999

"A linguagem da casa entre os negros no Recôncavo Baiano", Revista Mana, Rio de Janeiro, vol. 5(2): 31-60.

MARIZ, C. L. \& MACHADO, M. D. C.

1998

"Mudanças recentes no campo religioso brasileiro", Antropolitica, n. 5: 21-43.

NOVAES, R. C. R.

Os escolhidos de Deus: pentecostais, trabalhadores e cidadania, Rio de Janeiro, Iser.

REIS, João José

1996 .

A morte é uma festa: ritos fúnebres e revolta popular no Brasil do século XIX, São Paulo, Companhia das Letras.

SANCHIS, P.

1994

"Pra não dizer que não falei de sincretismo", Comunicaçôes do ISER 4 (A dança dos sincretismos), Rio de Janeiro, Iser. 
SARTI, C. A.

1996

A familia como espelho. Um estudo sobre a moral dos pobres, São Paulo, Autores Associados.

WEBER, Max.

Ensaios de sociologia, Rio de Janeiro, Livros Técnicos e Científicos.

ZIEGLER, J.

Os vivos e a morte: uma sociologia da morte no Ocidente e na diáspora africana no Brasil e seus mecanismos culturais, Rio de Janeiro, Zahar.

\begin{abstract}
This article approaches significant aspects of a broader research that focuses the complex situation of religious plurality in a low-class family network, as well as the consequent transformations in that family and neighborhood. The way how new choices towards each religious confession, specially pentecostal ones, affects the adoption of new attitudes are also studied. The funeral ceremonies of the couple that originated the family network are taken as examples of the tension between attribution (heritage) and acquisition (choice), represented in acceptance or refusal in taking active part in different religious rituals.
\end{abstract}

KEY-WORDS: family, religious plurality, family rituals, exclusivism.

Aceito em novembro de 2006. 